Western University Scholarship@Western

Centre for the Study of International Economic

Centre for the Study of International Economic

Relations Working Papers

Relations

1984

\title{
Rent Seeking and the North-South Terms of Trade
}

Bob Hamilton

Sharif Mohammad

John Whalley

Follow this and additional works at: https://ir.lib.uwo.ca/economicscsier_wp

Part of the Economics Commons

\section{Citation of this paper:}

Hamilton, Bob, Sharif Mohammad, John Whalley. "Rent Seeking and the North-South Terms of Trade." Centre for the Study of International Economic Relations Working Papers, 8426C. London, ON: Department of Economics, University of Western Ontario (1984). 
CENTRE FOR THE STUDY OF INTERNATIONAL ECONOMIC RELATIONS

WORKING PAPER NO. $8426 \mathrm{C}$

RENT SEEKING AND THE NORTH-SOUTH TERMS OF TRADE

Bob Hamilton

Sharif Mohammad

John Wha1ley

This paper contains preliminary findings from research work still in progress and should not be auoted without prior approval of the author.

DEPARTMENT OF ECONOMICS

THE UNIVERSITY OF WESTERN ONTARIO

LONDON, CANADA

N6A 5C 2

$$
\begin{aligned}
& \text { Depsitmank of Econonics Library } \\
& \qquad \text { MAY } 171984 \\
& \text { Universily of Westem Ontario }
\end{aligned}
$$


Rent Seeking and the North-South Terms of Trade ${ }^{1}$

\author{
Bob Hamilton \\ Sharif Mohammad \\ John Whalley \\ University of Western Ontario \\ Lond on \\ Canada
}

May 1984

${ }^{1}$ Earlier versions of this paper have been presented at the NBER Conference on Applied General Equilibrium Analysis, Stanford University, California, February 1984, and to a workshop group at Western Ontario. We are grateful to participants for comments. The third author wishes to acknowledge financial support from SSHRC, Ottawa. 
I. INTRODUCTION

This paper uses an eight-region numerical general equilibrium model of global production, trade, and demand in which both import licensing and rent seeking are present in developing country regions to analyze the impacts of changes in trade policies and differential factor growth rates on the North-South terms of trade. The model is similar to that used in earlier work on the impacts of global trade liberalization by Whalley (forthcoming). In the present paper import licensing enters the model as a set of quantity constraints on imports in developing countries rather than as ad valorem tariff equivalents, and rent-seeking activities generate wasteful factor use as rights to licenses (rents) are competed for.

This analysis is motivated by three separate observations.

1. Much of the work on the North-South terms of trade has focussed on the Singer-Prebisch hypothesis (Singer (1950) and Prebisch (1950)), that IDCs inevitably face a deterioration in their terms of trade over time. While rent seeking associated with import licensing in developing countries has been recognized in the literature, it seems to have gone unnoticed that this also has major implications for the debate on the North-South terms of trade. The effects of import licensing with rent seeking are similar to those of a tariff, except that the revenues from the trade restricting policy are dissipated through the resource costs associated with induced unproductive activities. As a result, there are different terms of trade for exporting and importing regions, since buying prices for importing 
regions (i.e., including incremental rent-seeking costs) and selling prices for exporting regions (i.e. excluding incremental rent-seeking costs) are no longer equal. Thus the is sue of whether the conventionally measured terms of trade is moving in favour of the North or the South (the North-South terms of trade issue as usually debated) may be largely irrelevant if import licensing has also been changing in severity over time.'

2. Most existing applied general equilibrium trade policy models (such as those summarized in Shoven and whalley (1984)) represent all trade protection policies, including non-tariff measures, in ad valorem equivalent form. Intuition clearly suggests that alternative specifications of the foreign trade regime can influence results, but thus far this issue has not been extensively investigated. As originally suggested by Krueger (1974), incorporating import licensing and rent seeking into these models should substantially change the measured welfare impacts of changes in trade restricting policies, due to the cost of rent seeking. Analysis of other trade policy arrangements in these models, such as international cartelization under the MFA, the transfer of rents to exporting countries through VERs or OMAs, or foreign exchange rationing, will also likely produce different

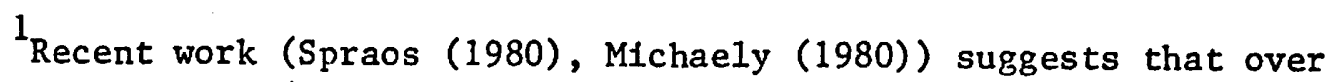
the post-war period the terms of trade of the South (as conventionally measured) has been improving, while the terms of trade of the North has been deteriorating. With increasing severity of licensing restrictions on imports in the South, the terms of trade of the South, appropriately measured to include incremental rent seeking costs, could also have deteriorated. Use of the elght-region global trade model with modifications to incorporate rent seeking and import licensing thus allows for an assessment as to whether both the North and South regions have experfenced deteriorating trade opportunities over time due to these features. 
policy conclusions if the current ad valorem treatment of these policies is modified.

3. Simultaneously incorporating ad valorem trade distortions and quantity constraints in an applied general equilibrium trade model can produce different conclusions as to the impacts of partial trade liberalization, compared to the currently used ad valorem approach. For instance, in the presence of quotas and rent seeking, tariffs decrease the size of rents if the tariff rate is less than the import premium created by the licensing restriction. If tariffs are reduced but licensing remains unchanged, this will be welfare worsening since rents, and hence the costs of rent seeking, increase. Thus, partial liberalization of developing country trade policies could be disadvantageous if reductions in tariffs alone occur, and import licensing and rent seeking remain.

The plan of the paper is as follows. In Sections II and III we outline the eight-region global trade model, along with the key data sources and parameter values. We also discuss how import licensing and rent seeking enter the model. Section IV presents results for a number of trade policy changes and differential factor growth scenarios. The main implications are summarized in the conclusion.

'Assuming, however, that there is no revenue seeking associated with the tariff (see Bhagwati and Srinivasan (1980)). With both revenue seeking and rent seeking, if the technologies of the two seeking activities are the same, reducing a tariff has no effects since the reduction in revenue seeking is offset by increased rent seeking as quota values rise. 
II. AN EIGHT-REGIONAL GENERAL EQUILIBRIUM OF WORLD TRADE

INCORPORATING IMPORT LICENSING AND RENT SEEKING

The eight-region general equilibrium model of global trade, production, and welfare used in this paper is essentially that described in whalley (forthcoming), but with the major difference that import licensing and rent seeking behavior in the developing country regions are explicitly modelled. The main features of the model are summarized in Table 1 . In its earlier (pre-rent seeking) form, this model is most easily thought of as a numerical trade model in the Heckscher-Ohlin tradition. Each region has both production and demand functions. Produced commodities are internationally mobile. Factors are internationally immobile but intersectorally mobile within each region. Equilibrium involves global demand supply equalities, and zero profits in each industry in each region. Tariffs and other trade policies change the equilibrium behavior of the model, and their effects are analyzed by comparing equilibria associated with alternative trade policy regimes. The main differences from a pure HeckscherOhlin trade model are differences in production parameters between regions, and the Armington assumption of product heterogeneity across regions.

\section{Regional and Product Detail}

Eight regions appear, reflecting major participants in world trade. These are the (nine-member) EEC, the U.S., Japan, Canada, Other Developed Countries (including USSR and Eastern Europe), OPEC, Newly Industrialized Countries (NICs), and Less Developed Countries (LDCs). The sizes of these regions in the model reflect their relative U.S. dollar GNP for 1977 taken from the World Bank Atlas. 
Main Features of the Eight-Region Global Trade Model

1. Mode1 Dimensions: Eight regions; ${ }^{1}$ six products $^{2}$ (one non-traded) produced in each region; two primary factors in each region which are intersectorally perfectly mobile, but internationally immobile.

2. Armington Assumption: Products are treated as qualitatively different, even if similarly labelled across regions, e.g., Japanese and U.S. cars are not perfect substitutes. Treatment adopted due to cross hauling in trade data, and desire to calibrate model specification to literature trade elasticities.

3. Production: Production of each product uses primary factors and other products (both domestic and imports) in CRS production processes. Primary factor requirements represented by CES value added functions with capital and labour services as.inputs. Intermediate requirements involve fixed coefficients in 'composite' goods, but substitution is allowed across sources of supply, i.e., a fixed requirement of steel per car produced in the EEC, but substitution between steel supplied by EEC, Japan, U.S., and other regions.

4. Final Demands: Each region generates demands from utility maximization subject to its regional budget constraint. Four-level nested CES/LES functions are used to provide required flexibility on: income and price elasticities.

5. Trade Distorting Policies: Each region has tariffs, non-tariff barriers (NTBs), and domestic tax policies. In developed country regions, NTBs appear in ad valorem tariff equivalent form. In the developing country regions import licensing. (along with rent seeking activity) is incorporated.

6. Equilibrium: Set of prices for goods and factors in all regions such that (i) demands equal supplies for all goods and factors (ii) no industry makes above normal profits (zero profits after allowing for return to capital). In equilibrium, government budgets are balanced in each region from the regional budget constraints.

7. Choice of Parameter Values: Model calibrated to 1977 global benchmark equilibrium data set (i.e., reproduces the se data as a model equilibrium solution if there are no policy changes). Elasticities in CES functions, and minimum requirements in LES functions need to be specified prior to calibration. Literature search used for these key values.

8. Key Parameter Values for Model Results: (i) trade protection policies; tariffs and NTB ad valorem equivalents in developed countries, tariffs and import premia due to licensing in developing countries (ii) trade elasticities: elasticities of substitution between domestic and foreign products in demands and intermediate production.

9. Mode1 Use: Counterfactual Equilibrium Analysis, i.e., hypothetical equilibrium under complete adjustment to changes in trade policy regimes in one or more regions.

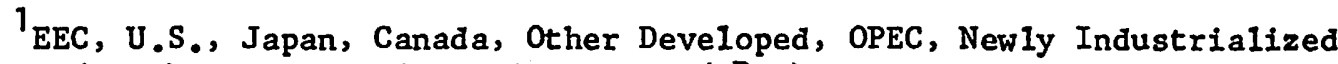
Countries (NICs), Less Developed Countries (IDCs).

${ }^{2}$ Agricultural Products; Mineral Products; Energy; Non-Mechanical Manufacturing: Machinery and Transport Equipment; Construction, Services, and Other Non-Traded Goods. 
Six products are produced in each region: Agriculture and Food; Minera1 Products and Extractive Ores; Energy Products (including oil); Non-Mechanical Manufacturing; Machinery and Transport Equipment (including vehicles); Construction, Services, and other Non-Traded Products. Each of the first five goods is internationally traded with an as sumed heterogeneity by region across production sources. The sixth commodity is nontraded for all regions.

The same commodity classification is used for trade, domestic production, and final demand data, with an approximate concordance between different classification systems in basic data. The model incorporates less product detail than the full version of the four-region model (Whalley (1982)) which identifies 33 commodities in each region. Problems of data availability for all regions on this classification, plus the large dimensions involved in solving for an equilibrium in an eight-region model have limited the dimensionality to six products and eight regions; 48 . products in total.

\section{Armington Assumption}

Products are differentiated on the basis of geographical point of production as well as by their physical characteristics, with 'similar' products being close substitutes in demand. Japanese manufactures, for instance, are treated as qualitatively different products from U.S., EEC, NIC, or other manufactures. This is often referred to as the Armington assumption, following Armington (1969).

This assumption of product heterogeneity by region is used both to accommodate the statistical phenomenon of cross-hauling in international trade data, and to exclude complete specialization in production as a behavioral response in the model. This treatment also enables empirically based import demand elasticities to be incorporated into the model specification. 
Demand and Production Functions

Substitution possibilities in both demand and production for each region are incorporated through CES functions. Elasticities of substitution in these functions determine price elasticities in both goods and factor demand functions. Because of the Armington product heterogeneity assumption, these elasticities also control import and export demand elasticities for any region, and thus affect terms of trade impacts of policy or other model changes.

The hierarchical structure of substitution possibilities used in these functions is outlined in Table 2. On the production side, each industry has a CES value-added function which specifies substitution possibilities between the two regional primary factor inputs, capital and labour services. These are both treated as perfectly mobile intersectorally within regions, but immobile between regions. There is assumed to be no technical change.

In addition to CES value-added functions, substitution between intermediate products is incorporated. Fixed coefficients in terms of composite goods are assumed, but each fixed coefficient requirement of composite goods is a nested CES function with elements of the composite (products identified by the region in which they are produced) entering as arguments. Substitution occurs between comparable domestic and composite imported commodities at the top level of nesting, with further substitution taking place between import types differentiated by location of production. 1

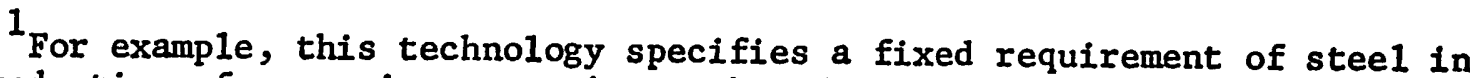
the production of a car in any region. This fixed steel requirement can be met by a substitutable $\mathrm{mix}$ of domestic and imported stee1. Imported steel, in turn, is a composite of the various types of steel available (differentiated by location of production) with substitution between each. Were the model to separately identify steel as a commodity, the substitution elasticity between domestic and imported steel would be the major determinant of the price elasticity of the demand for steel imports. Substitution between types of steel affects the price elasticity of the demand function facing individual exporting regions. 
Table 2

Hierarchy of Substitution Possibilities

in the Eight-Region Trade Model

DENiD

\section{PInel Demand Funcelong}

la each region, a 4 level CES/LES

functional form to used.

\section{CES Alerarchy}

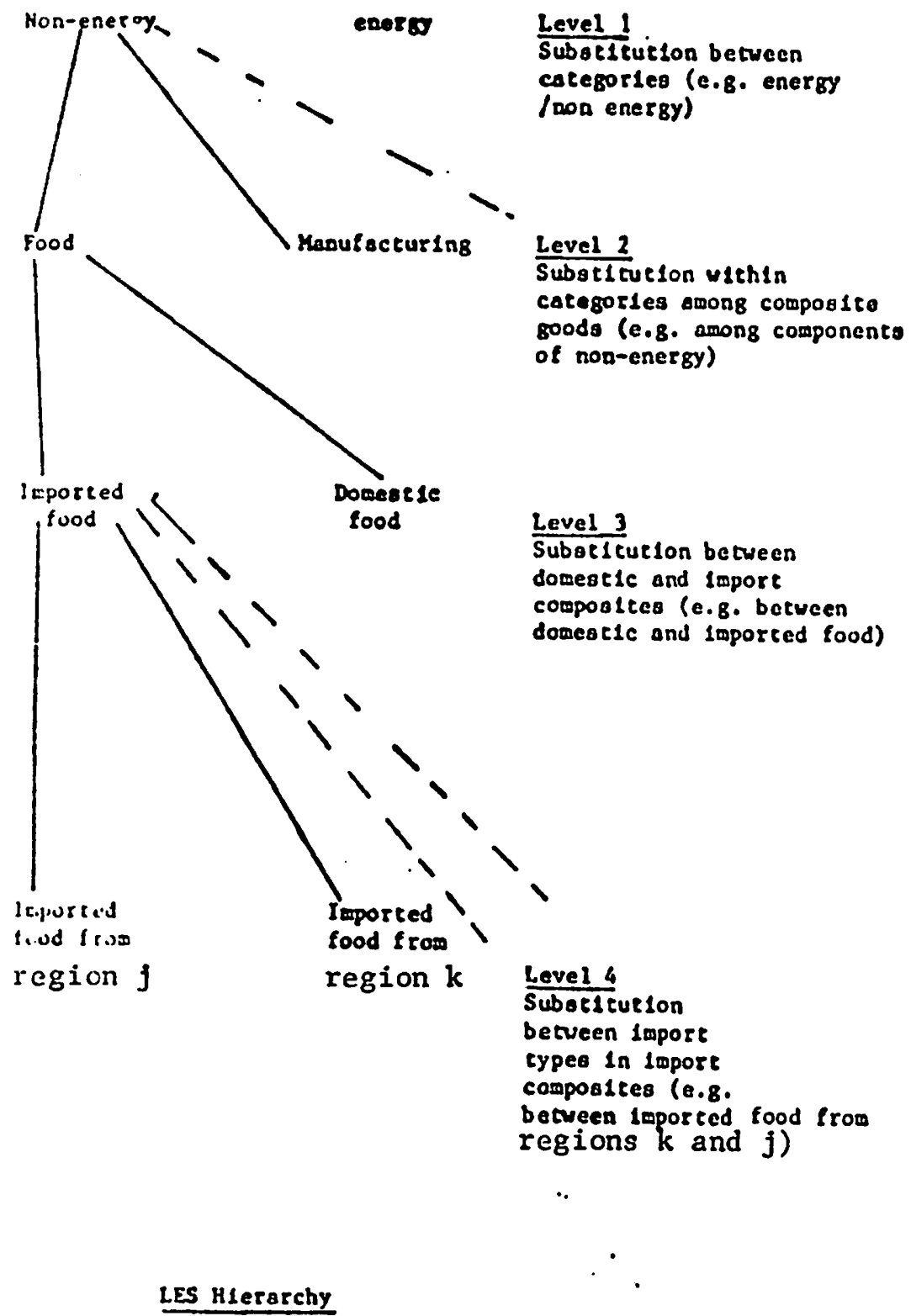

\section{PEODOCTIOA}

Value added Functlona

Each Industry in each region has - CES value added funcelon usch captial and labour oervices as prieary inputs

\section{Intermed late Subatituelon}

Plxed coefficlent Intermedlace requirements technology, but with each fixed coefficlent expreased In terms of compositeo only (1.e. a flxed machlacry requiremeor per unte of monufactur (og).

Each fixed coefflclent Inpue requirement met by coot mintmleing bundle of dómestlc and Import composices obralned from CES oubatitution functions.

\section{CES hierarchy (For each flxed coefflclent 1a terms of compooltes e.g. mechinery requiresent per und of manufacture).}

P1xed Mnchlnery Requlrement

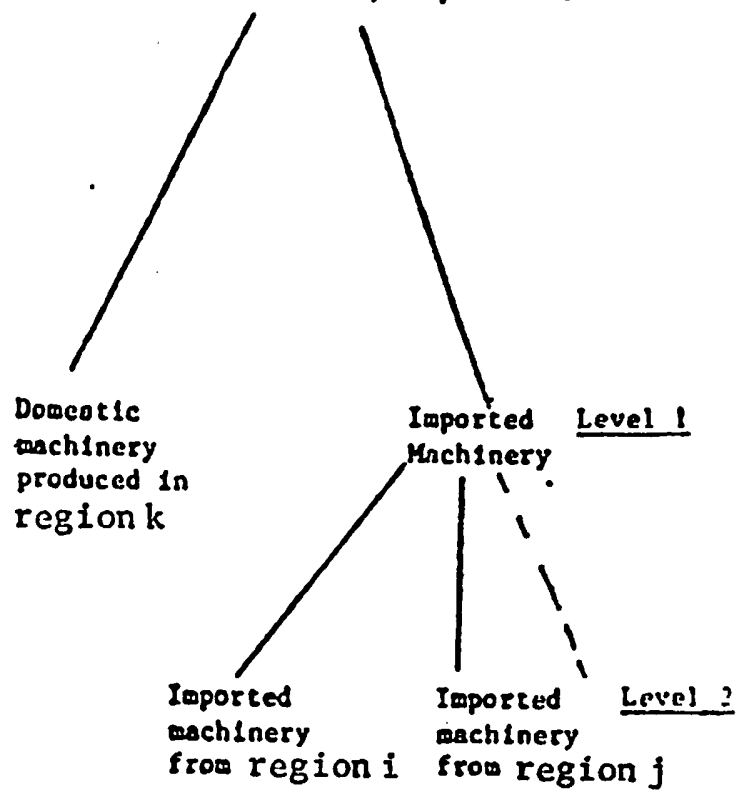

Minicum requirements for each licpurt composite at level 3 uoed, These allow Income plasticities for 1epurt demands to be different frow unity. 
On the demand side of the model a single set of final demand functions is specified for each region. These are obtained by maximizing a nested CES/LES utility function. Within the hierarchy of demand side substitution possibilities, elasticities separately control substitution between similar products imported from the various regions, and between composites of imports across import sources and comparable domestic products. Two final levels of elasticity values determine substitution between the composite domestic-import products. ${ }^{1}$ The LES features of the demand functions specify minimum requirements for commodities appearing in the nesting structure.

Use of these nested functions enables empirical estimates of income and price elasticities in world trade to be incorporated into the model. Iiterature estimates of import and other price elasticities guide parameter choice for inter-nest elasticity values in the CES functions (i॰e., between 'similar' products subscripted by location and production). The LES features in the hierarchy allow income elasticities in import demand functions to differ from unity.

Since each region generates demands from utility maximization, the market demand functions in the model satisfy Walras' Law. This is the condition that at any set of prices the total value of demands equals the total value of incomes. The incomes of regions are derived from the sale of primary factors owned by each region plus transfers received, including foreign aid. Incomes in the developing country regions incorporate the real income loss from rent seeking associated with import licensing.

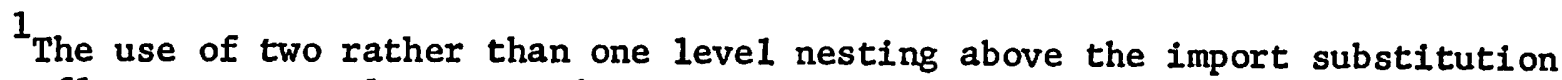
stage reflects a general purpose design of the model, not exploited in the present paper. Future applications of the model to world energv trade are anticipated, and the price elasticity of energy demand would become a key parameter in such an analysis. The need to separately treat energy in such an analysis explains the presence of this additional level of flexibility in the nesting. 


\section{Treatment of Trade Policies}

Earlier versions of the present model incorporate forelgn trade policies in each region as ad valorem equivalents. These include tariffs, non-tariff barriers (NTBs), and certain features of domestic tax policies. This treatment remains unchanged for the five developed country regions plús OPEC. However, for the newly industrialized and less developed countries modifications have been made to incorporate import licensing and associated rent seeking activities in place of the ad valorem equivalent treatment.

The most important of these accommodate quantity constraints on imports along with the resource costs associated with rent seeking as competitive rent seekers attempt to secure rights to the rents created by the controls. An approach similar to that in Shoven and whalley (1972) is used which incorporates price distortions through the artificial device of tickets which must be purchased each time a quantity constrained commodity is acquired. ${ }^{1}$ The price of tickets is endogenously determined in equilibrium, and the quantity of tickets reflect the quota allotment associated with import 1 icensing.

Two artificial commodities (import tickets) are specified, one of which must be purchased each time a dollar of imports is brought into either of the two developing country regions (LDCs and NICs). If import quantity constraints are modelled to operate on a commodity rather than a regional basis, a separate artificial commodity is required for each quantity

$1_{\text {This earlier paper was a first attempt at specifying a general }}$ equilibrium tax model in which ad valorem tax discortions were approximated through a quantity constraint. The purchase of one unit of the artificial ticket commodity was required whenever a factor of production was employed in the taxed sector. The severity of constraint was parametrically varied until the desired ad valorem distortion was approximated. 
restriction. To keep model dimensions manageable, quota restrictions in developing country regions are assumed to apply in value terms across all imports into each region. A system of commodity rather than import value quotas would involve solving a much larger dimensional equilibrium model than used here.

The quantity of import tickets available in each region determines the severity of import licensing, and the price of each ticket is endogenously determined so as to clear the market for each ticket type in equilibrium. Domestic buying prices for imports include the cost of tickets, and therefore reflect the import premia which prevail in developing country regions (differences between domestic prices and world prices).

Rent seeking associated with import licenses involves factor use in importing regions as competitive rent seekers seek out rights to import tickets (quotas). The factor endowment of the importing region is proportionally reduced with the value of factor loss equalling the value of tickets (the welfare cost of rent seeking equals the value of rent created). This treatment involves the same two assumptions as in Kreuger (1974); namely, that rent seeking is a constant marginal cost activity, and that rents are fully sought. The latter is a contentious assumption since if licenses are auctioned or distributed according to rules which remove incentives for rent seeking (such as a lottery), this treatment will overstate the effects of rent seeking. As a result, we later perform sensitivity analyses in which we assume that only one-half the value of rents is sought.

The precise mechanics of the competitive rent-seeking process are not specified in the model. However, the way this process works are 
documented in the literature. In India, for instance, import quotas are partly awarded on the basis of 'need' as demonstrated by the capability of a firm to use imports. As a result, there is frequently over-investment in capacity to demonstrate such need, generating the of ten quoted paradox of low capacity utilization rates (as low as 25 percent in some industries) in a capital scarce economy. These and other features of rent seeking in India are discussed more fully in Mohammad and Whalley (1984).

Since wasteful resource use is divided proportionally between capital and labour on the basis of the value of endowments in each of the regions, the income loss from rent seeking is easily incorporated into the model. The income of the importing region equals factor incomes at factor prices, excluding the revenue which would otherwise accrue from sale of import tickets. The revenue from the trade distortion does not appear as income to the economy, due to the income loss from rent seeking activity. The excess demand factor functions for capital and labour in each region in the model are modified to include the resources used in seeking rents.

\section{Data on Trade Distortion Parameters}

The data used to represent trade restricting policies in the model rely on a variety of sources. For four of the regions in the model single countries are involved and the trade policy regime represented by that country alone. For the other four regions, composites of countries are involved making numerical representation of the trade policy regime more difficult.

In the model trade protection policies in developed countries are relatively mild in aggregate, but have sharply discriminatory impacts on particular products. On the other hand, highly protective trade policies operate in developing countries. This specification reflects the 
feature that trade policies in developed countries have been subject to negotiated reductions under the GATT in the post-war period, while trade policies in developing countries have remained largely unaffected by such negotiations .

Tariff data by product for the developed country regions are taken from a 1976 data file prepared by the U.S. Special Trade Representatives Office from the GATT Tariff Study for that year. For the developing country region, estimates from Balassa (1971) are used. Ad valorem equivalent NTB estimates for developed countries draw on a number of sources which estimate the additional protection from NTBs beyond that due to the tariff. Among others, the estimates by Yeats (1978) are used which draw on UNCTAD data to estimate NTB equivalents by a residual method using differences between domestic and world prices. For developing countries, estimates of import premia due to import licensing are used, although relatively few studies exist upon which to base the specifications of these parameters. Most studies are for India, Pakistan, or Bangladesh. These suggest that on average the margin between landed prices of imports (gross of tariffs) and market clearing prices is approximately 100 percent, and maybe even more.

Bhagwati and Srinivasan (1975), for instance, report that for India import premia on most metals and metal products, steel products (such as sheets and wires), chemicals, paper products, glass, and machinery, etc. were between 70 to 100 percent or even more in 1968-71. These premia were higher before the June 1966 rupee devaluation than for the period studied intensively by Bhagwati and Srinivasan, and ranged from 125 percent on licenses for drugs and medicines to 350 percent on steel products. Indications seem to be that foreign exchange shortages after the oil price rise of the 1970s have increased these premia further. 
Similar estimates appear in a recent study for Bangladesh by Bhuyan and Mahmud (1979) using data for 1978-79. Despite high tariff rates and other taxes on imports, the margin between the landed price (inclusive of tariffs and sales tax, etc.) and the free market price of imports is approximately 100 percent for a large number of commodities. For several items margins are in the 200 percent range.

In another study of Pakistan for the years 1966-67 (including Bangladesh), Alamgir (1968) estimated import premia to be approximately 70 percent. Pakistan had earlier attempted to liberalize trade in a number of items through a bonus scheme during this period, but premia were still found to be rising over time on most of the items studied.

Given the simplified model treatment of a single quantity constraint in value terms on imports for each of the developing country regions, a single estimate for the aggregate import premia of 100 percent is specified for each of the two regions. This premium value appears in the benchmark equilibrium data set to which the model is calibrated. This contains micro consistent data on global trade and production for 1977 in the presence of existing trade policies.

\section{Equilibrium in the Model}

Different equilibria for the model are computed under various changes in trade policies and factor endowments (which reflect the effects of growth) and compared to 1977 benchmark equilibrium data to which the model is calibrated. The solution concept used for the model is that of a global equilibrium. In equilibrium, producers maximize profits and competitive forces operate such that all supernormal profits are competed away. Demands equal supplies for all products, and in each industry in each region a zero-profit condition is satisfied. A zero foreign external sector balance condition (including 
investment flows, dividends, interest, and transfers) ${ }^{1}$ applies for each

region from the regional budget constraints.

Production and demand in each region respond to changes in both

domestic and world prices. For each product the market price in the model is

the price at point of production. Sellers receive these prices, purchasers

(of both intermediate and final products) pay these prices gross of trade

policy margins and domestic taxes; no transportation costs are considered.

III. BENCHMARK CALIBRATION, ELASTICITIES, AND

EQUILIBRIUM SOLUTION OF THE MODEL

Parameter values are determined for the model by calibrating to the 1977 benchmark equilibrium data giving trade, production, and demand for each region. This procedure is used to determine parameter values for the model functions consistent with both the data and model equilibrium conditions. Counter-factual analysis then proceed for any specified trade policy or other change. A flow chart outlining this procedure is given in Table 3.

\section{Calibration}

The calibration procedure begins with the construction of a data set for a given year in a form which is consistent with the equilibrium solution concept of the model; a benchmark equilibrium data set. The 1977 micro consistent benchmark equilibrium data set used satisfies the conditions for a worldwide competitive equilibrium that demands equal supplies

\section{1}

Investment flows, interest and dividends, and foreign aid appear in the model, with the second two of these being treated as income transfers. Foreign investment is treated as purchase of capital goods by agents located in the region of source of capital funds. The difference between investment flows and merchandise trade is that the capital goods acquired are not repatriated to the region where the purchaser is located, but remain in the source region. These will, of course, generate income in future time periods, but no dynamic features enter the model. The future income stream from capital goods underlies their appearance in utility functions, but there is no explicit interest elasticity of either savings or international capital flows. 
TABLE 3

MODEL FLOW CHART FOR WORLD TRADE GENERAL EQUILIBRIUM MODEL

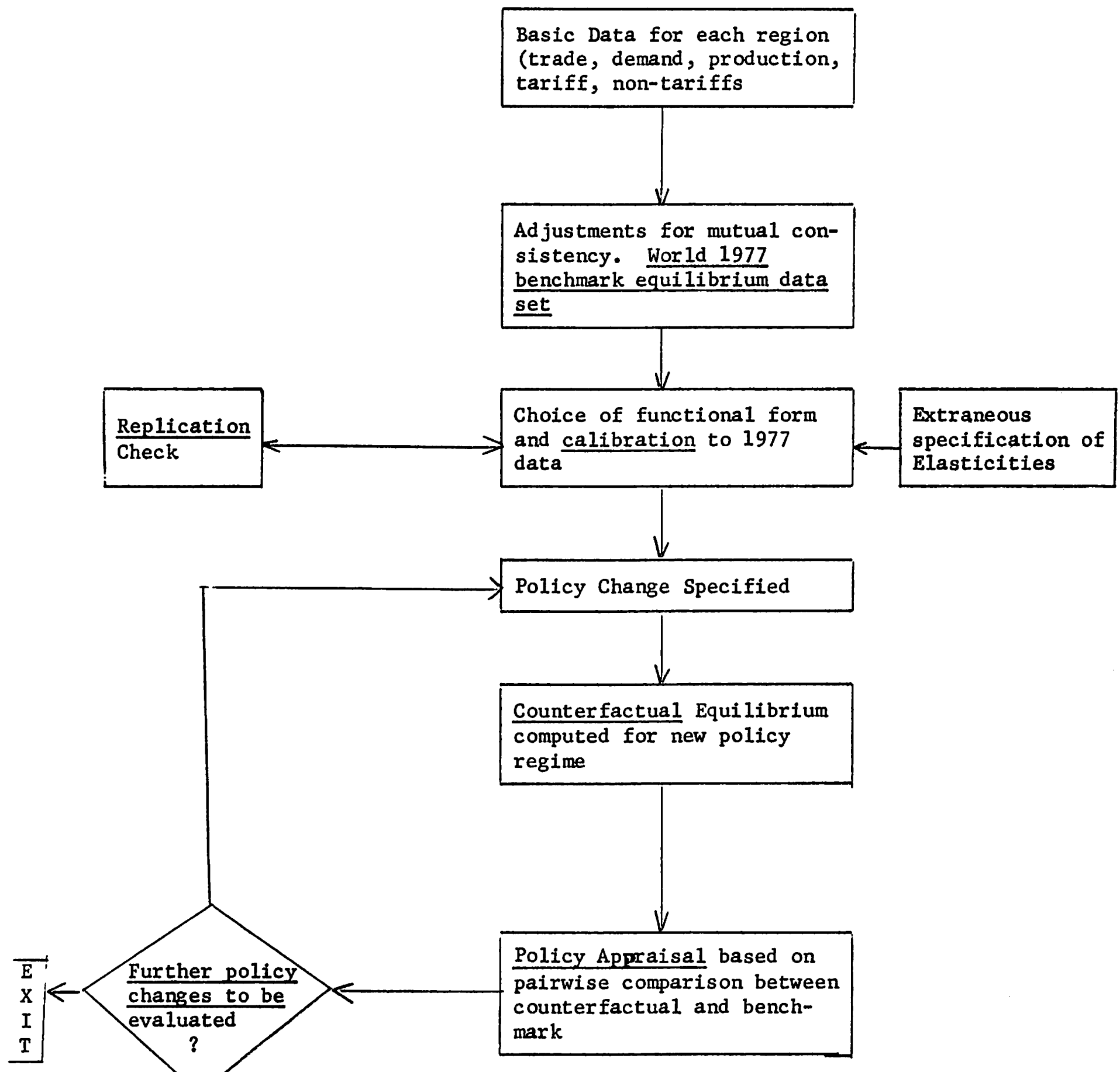


for all products, no profits are made in any of the domestic industries, and each region is in zero external sector balance. Many divergent source materials are used, and need adjustment for inconsistent classification and definitions. In addition, further modifications are necessary to mutually adjust the data so that the equilibrium conditions of the model are satisfied. The assembly of data on such a scale inevitably involves a substantial degree of summary judgement and accommodation between data of varying quality. Outside of data on import premia in developing country regions, a description of the sources and methods used appears in whalley (forthcoming). Once assembled, parameter values for the model equations are directly calculated from the equilibrium conditions using the calibration procedure described in Mansur and Whalley (1984). This involves a nonstochastic procedure, which takes the model equilibrium conditions and solves for parameter values from equilibrium observations.

Because of the CES/LES functional forms used, implementing this procedure requires more information than that contained in the benchmark equilibrium data set. For instance, on the demand side benchmark data yield equilibrium consumption bundles and slopes of budget constraints. With Cobb-Douglas preferences this is enough information to infer the parameters of the utility function, but this is not the case with CES/LES functions. These additional informational requirements are met by specifying elasticities of substitution and minimum requirements in the functional forms 
which imply particular values of income and own price elasticities. The choice of these values reflects literature estimates. Once these parameter values are specified, share paraneters are determined consistent with both equilibrium prices and quantities. On the supply side, cost functions are similarly solved for share and unit parameters consistent with equilibrium prices and input use by industry.

The model specification is then capable of reproducing the benchmark data as an equilibrium solution to the model, and comparative statics can be performed with the model by computing new equilibria for alternative trade policy regimes or growth scenarios.

\section{Elasticity Specification}

The values chosen for substitution elasticities when the model is calibrated can have a substantial impact on the results produced by the model. Although a number of different elasticity values need to be specified for both the demand and production sides of the model, an especially important set of parameters are the substitution elasticities which determine import demand elasticities.

In Table 4, literature survey (predominantly time series) import price elasticities and export price elasticities are reported by region, based on a number of literature sources which are used to guide parameter choice in the model. This table suggests import price elasticities in the neighbourhood of unity and export price elasticities a little higher. Import price elasticities for developed countries are based on the Stern, Francis, Schumacher (1977) compendium of trade elasticities, and estimates for developing countries are due to Khan (1974). 
Table 4

\section{Literature Survey Trade Elasticities}

Used in the Model

\begin{tabular}{lll} 
& \multicolumn{1}{c}{ 'Central Tendency' } & $\frac{\text { 'Central Tendency' }}{\text { Import Price }}$ \\
Trading Area & $\frac{\text { Elasticities }}{\text { Elasticities }}$ & -1.14 \\
EEC & -.91 & -1.41 \\
US & -1.66 & -1.25 \\
JAPAN & -.78 & -0.79 \\
CANADA & -1.30 & -1.26 \\
OTHER DEV. & -1.02 & -0.83 (Venezuela) \\
OPEC & -0.89 (Venezuela) & -1.41 (Turkey) \\
NIC & -1.38 & -1.82 (Pakistan) \\
LDC & -1.28 &
\end{tabular}

Sources: EEC - Weighted average over country 'best guess' estimates suggested by Stern, Francis and Schumacher (1976) from their literature survey, and Houthakker/Magee (1969)

US - Stern, Francis and Schumacher 'best guess' plus Houthakker/Magee

JAPAN - Stern, Francis, and Schumacher 'best guess' plus Houthakker/llagee

CANADA - Stern, Francis, Schumacher 'best guess' plus Houthakker/Magee

OTHER DEV. - Arithmetic average over EEC, U.S., and Japan, plus Houthakker/Magee

NIC - Estimates for Uruguay, Colombla, Brazil, Argentina, and Turkey reported by Khan (1974), Weisskoff (1979), and Taplin (1974)

LDC - Estimates for Bangladesh, Sri Lanka, Philippines, Pakistan, Morocco, Ghana, India, and Ecuador due to Kahn (1974), Nguyen and Bhuyan (1977), and Houthakker/Magee (1969) 
While these ranges reflect the current consensus on trade elasticities, their use should not pass without comment. Several authors have raised difficulties with time series estimation of trade elasticities. Orcutt (1950) long ago suggested specification bias, and Kemp (1962) suggested that errors in measurement of import price indices may lead to a bias toward unity. Trade researchers frequently argue that time series estimates are too low, and some (such as Balassa and Kreinen (1967)) have used significantly higher values. In spite of these reservations, estimates of this type are still commonly employed and are also used here. Time series estimates provide the main source for the compendium of trade elasticities produced by Stern, Francis, and Schumacher (1977). Estimates for the U.S., EEC, and Japan by Stone (1981) which also provide detailed product-by-product estimates are approximately consistent with the values reported in Table 4. Some further recent detailed product estimates by Shiells, Stern and Deardorff (1983) are a little higher (in absolute value) than the estimates reported in Table 4.

\section{Equi librium Solution}

Once specified, the model is solved for a new general equilibrium for a policy or other change using a Newton-type procedure involving an estimate of the Jacobian matrix of excess factor demands and government budget imbalances. For the type of general equilibrium problems solved with this model, this method works more rapidly than Scarf's algorithm ${ }^{1}$ or the restart methods of Merrill and others. Although there is no ex ante argument of convergence with the computational procedure used, it has been successful in implementation.

A final point is that although no guarantee of uniqueness of equilibrium is available for the model, there is circumstantial evidence to support

${ }^{1}$ See Scarf (1973) and the extension to international trade models with tariffs by Shoven and Whalley (1974). 
uniqueness. With numerical solution of similar models, a range of experimentation on this issue has been performed. Once an equilibrium is found, models are displaced from their equilibrium values to check that the same equilibrium is returned to. Also the same equilibrium can be approached from different starting points, and at different speeds. None of these tests has revealed a situation of non-uniqueness in these models (see Kehoe and Whalley (1982)).

\section{RESULTS}

In this section we present our results on the effects of growth and trade policy changes on the North-South terms of trade in the presence of import licensing and rent seeking. The issues concerning the North-South terms of trade involve two quite separate strands. One is the suggestion due to Singer and Prebisch that there is an inevitable deterioration in the terms of trade of the South over time because of their faster growth. This was originally based on statistical observations of changes in the U.K. terms of trade between 1870 and 1936, but the claim is sometimes made that this deterioration also applies more widely in the post-war period. The second strand of the debate focusses on the role of protectionist policies in the North, with the claim that developed country trade policies, such as textile quotas under the Multi-Fibre Arrangement (MFA), are disadvantageous for the developing countries and adversely affect the South's terms of trade.

An argument supporting the Singer-Prebisch thesis is that in absolute terms the economies of the South are more rapidly growing, due to higher population growth. In turn, their exports tend to be necessities which have low income elasticities in the import demand functions of the North, whereas their imports are luxuries with high income elasticities. In this case, even with uniform real growth in the global economy a deterioration in the terms of trade in the South results. 
We have used our model to analyze these issues while recognizing the presence of both import licensing and rent seeking in developing country regions. As emphasized in earlier sections, if the severity of the import controls with which rent seeking are associated changes, the measured impacts of differential growth rates across regions on the terms of trade will be different from a model which ignores this feature. In the extreme case where full rent seeking accompanies import quotas, there is no longer one single international terms of trade since the incremental cost of the rent seeking also has to be taken into account in calculating the terms of trade of importing regions.

Table 5 reports annual factor growth rates by region used in the analysis of the impact of differential regional growth rates on the North-South terms of trade. (1981 World Development Report estimates of annual growth rates of GNP are used.) Higher growth rates for Japan than other developed countries reflect their stronger economic performance of recent years, whereas higher growth rates for the NIC and IDC regions reflect higher population growth rates. As in the immiserizing growth literature (Bhagwati (1958)) the model treatment of growth is to assume that exogenous growth rates apply to the factor endowments of each region; annual growth rates are assumed to be unchanged over the periods analyzed.

Table 6 reports model results on the impacts of differential growth rates on the terms of trade by region, with and without import licensing and with rent seeking of differing degrees of severity. Two different types of analyses are presented in this table. In one we examine the effects of differential growth where licensing is absent in all years. In the second, licensing is present in all years. Iicensing is incorporated through the quota allocation mechanism described in earlier sections, with the quantity of tickets (quotas) increasing at the same growth rate as that of the factor endowments in the region. In two sub-cases the severity of rent seeking varies between full and partial (50\%) rent seeking. 
Table 5

Annual Factor Growth Rates Assumed in Analyzing Impacts of Differential Growth by Region on the North-South Terms of Trade ${ }^{1}$

$\begin{array}{ll}\text { EEC } & 3.3 \\ \text { U.S. } & 2.8 \\ \text { Japan } & 4.8 \\ \text { Canada } & 3.8 \\ \text { Other Developed } & 4.1 \\ \text { OPEC } & 3.5 \\ \text { NIC } & 5.2 \\ \text { LDC } & 4.5\end{array}$

1Source: 1981 World Development Report: The World Bank, Washington, D.C. 
Where controls are absent in all years, the effects of growth over 10 or 20 years are much the same as produced by earlier versions of the present model which excluded rent seeking and import licensing. (see Whalley (1984)). Over time, growth results in a deterioration in the terms of trade of faster growing regions. Differential growth over 20 years produces a deterioration in the Southern terms of trade of $12-14 \%$; over 10 years, a deterioration of $7 \%$ occurs. In his earlier paper Whalley suggests that the deterioration over 10 years is approximately equivalent to the annual terms of trade loss IDCs suffer as a result of protection currently being pursued in the North.

These estimates are sharply modified when rent seeking and import licensing are incorporated into the analysis, even when quotas are assumed to grow at the regional growth rates. Two different terms of trade estimates are reported for both IDCs and NICs for these cases. One is the terms of trade as conventionally measured, and excludes incremental rent seeking costs. The second includes the incremental rent seeking costs facing importing regions when acquiring additional imports.

The difference in results is accounted for by the way import licenses enter the analysis. With no licensing restrictions the growth rate of imports by importing regions would be lower than their factor endowment growth rate because they are the faster growing regions, but in this analysis the quantity of licenses increases at their own growth rates. This case therefore involves a partial liberalization of import licensing in the developing country regions. As a result, the conventionally measured terms of trade deteriorates more for NICs and LDCs than in the no-licensing case, and a larger terms of trade improvement occurs for the developed countries. On the other hand, including the incremental costs of rent seeking in the terms of trade measure changes the conventionally measured deterioration to an improvement in the full rent-seeking case, and sharply 


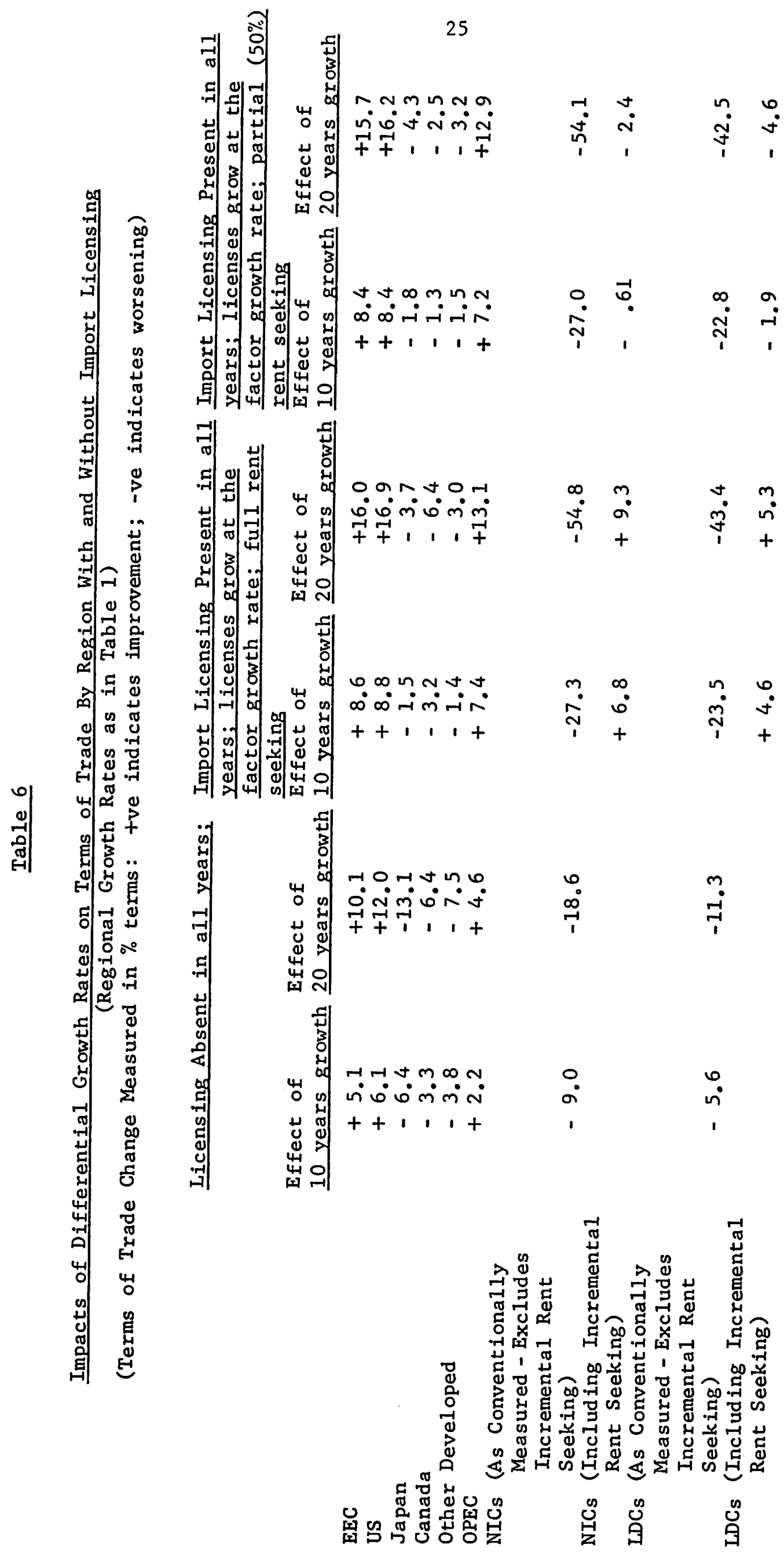


reduces the loss under partial rent seeking. With a more liberal licensing system import premia fall, and the costs of rent seeking are lower.

These results therefore suggest the importance of incorporating both import licensing and rent seeking into the analysis of trade liberalization as it affects both developing and developed countries. Depending on the severity of licensing and the import premia created large rent seeking costs can result, which can have a major impact on model results.

This same theme also appears in results in Table 7 , where differential growth rates and their impacts on the terms of trade by region are analyzed for cases in which there is increasing severity of import licensing through time. The assumption is that in the initial years there is no licensing, while in the terminal years licensing of the same severity as in the benchmark equilibrium is present.

While the growth rate assumptions used imply that in a no-licensing case there would be a terms of trade deterioration against the faster growing regions, the increasing severity of licensing sharply reduces the conventional terms of trade deterioration against the faster growing regions compared to results reported in Table 6 . In all cases, the terms of trade of Japan, Canada and other developed regions worsens, and in three of the six columns the terms of trade of the EEC and the U.S. also worsens.

Thus, increasing severity of import licensing in developing countries can cause a terms of trade deterioration of the North, a point little recognized in the debate on the North-South terms of trade. In literature on the statistical measurement of North-South terms of trade, Michaely (1980) and Sproas (1980) have both documented recent data on this issue, and suggest that even allowing for changes in the relative prices of oil, the terms of trade of the North may well have deteriorated in the period since 1950. Results in Table 7 


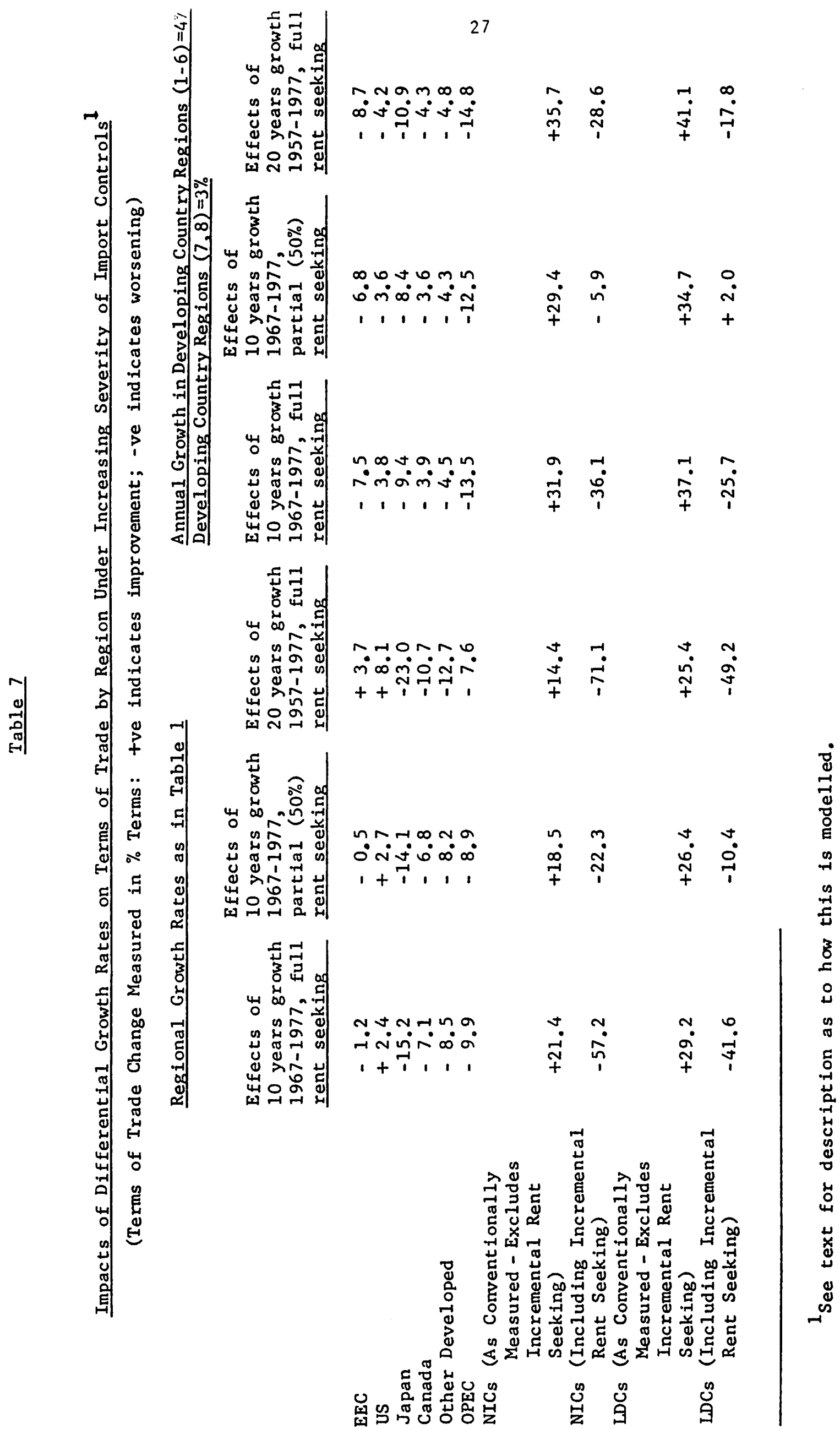


suggest that such a finding may in part be due to the increasing severity of import controls in the South.

Even more striking is the difference between conventionally measured terms of trade effects from differential growth, and those including incremental rent seeking costs. When incremental rent seeking costs are included, not only is there a terms of trade deterioration for the North, a terms of trade deterioration for the South also results from differential growth and import restrictions of increasing severity. As import restrictions become more severe, the welfare cost of rent seeking correspondingly increases, and the terms of trade of the import region (taking account of these incremental costs) also deteriorates. In columns 4 through 6 differential annual growth assumptions of $3 \%$ and $4 \%$ between the North and the South are assumed so as to generate a Northern terms of trade deterioration in the no-licensing case. However, because of the increasing severity of controls, a conventionally measured terms of trade improvement of the South is transformed into a terms of trade deterioration of approximately equal numerical size.

These results, therefore, suggest an alternative view of recent trends in the terms of trade between the North and South to that often heard. Debate on this issue has concentrated on whether the terms of trade of the North or the South are improving, with the presumption that if one region is improving its terms of trade the terms of trade of the other region must be deteriorating. Results in Table 7 suggest that because of rent seeking, there will no longer be a single terms of trade characterizing exchange between these two regions. With increasing severity of rent seeking over time, the terms of trade of both regions could easily be worsening and by substantial amounts.

The results reported in Table 8 focus on trade policy changes in the NICs and LDCs. In column 1 the effect of tariff abolition in NICs and LDCs is reported for a model variant where import licensing and rent seeking are not explicitly 
modelled (import premia determine the size of ad valorem tariff equivalents). In this case, there is a welfare loss to the LDCs and NICs, and a corresponding welfare gain for the EEC and the U.S. This is because a terms of trade deterioration occurs for IDCs and NICs as they move below their optimal tariff. A $20 \%$ deterioration in the terms of trade of LDCs and NICs occurs, along with a sharp improvement in the terms of trade of the EEC, U.S. and Japan. This result is indicative of a theme prominent in results from earlier versions of this mode1, that the terms of trade effects associated with large unilateral changes in protection can be pronounced (depending upon the trade elasticities used).

In the second column of Table 8 results are reported for comparable cases, but where import licensing remains unchanged along with rent seeking when tariffs are abolished. In this case there are even larger welfare costs for LDCs and NICs because of the creation of extra rents (and hence extra rent seeking costs) when tariffs are eliminated. There are small terms of trade improvements for developed countries. The main impact of the policy change is an income effect rather than a substitution effect, since imports in developing countries are quantity constrained, rather than directly affected by changes in the tariff. A small substitution effect (reflecting the model treatment of import licenses applying in value rather product specific terms) outweighs the income effect producing a terms of trade improvement for developing countries.

Columns 3 and 4 report results for similar cases to column 2 , but where the import price elasticities are changed in all regions. Unlike other policy changes considered with earlier versions of this model, these elasticity variations have relatively little impact either on the estimates of the welfare impacts of the policy change or the terms of trade effects. This is because 
Table 8

Effects of Tariff Abolition In NICs and LDCs

(1)

No Rent Seek1ng

(No Import

Controls Remain) after the tariff abolition)

(2)

(3)

(4)

W1th Full Rent W1th Full Rent Seeking but all Import price elasticities equal to 0.5 in all regions
With Full Rent Seeking but all import price elasticities equal to $2.0 \mathrm{in}$ a11 regions

A. ANNUAL WELFARE IMPACTS

(EVs in 1977 s b111)

EEC

18.7

4.9

3.8

5.7

6.8

1.2

1.1

1.3

11.2

3.4

2.2

4.3

1.2

$-.0$

.1

$-.0$

4.2

$-.5$

$-.3$

$-.8$

OPEC

$-1.9$

$-1.1$

$-2.5$

$-18.2$

$-38.5$

$-29.8$

$-42.1$

LDCs

$-11.3$

$-40.1$

$-36.4$

$-42.6$

B. TEKMS OF TRADE IMPACTS

(\% change; +ve denotes improvement)

EEC

6.9

2.6

11.1

1.8

1.1

2.7

OPEC

I'ICs (1s: ronventionally Mcasured Lissluding Incremental Rent تccl:1!ng)

$\mathrm{NiCs}$ !Inclut:Ins Incremental zent Seeking)

LDCs (As Conventionally Measured Excluding Incremental Rent Seeking)

LDCs (Including Incremental Rent Seeking)

$-22.0$
1.9

.4

3.5

$-.1$

$-.4$

$-1.6$

$-3.0$

$-18.3$

$-15.3$

$-2.2$

$-14.9$

$-17.5$

2.3

.5

4.5

$-\quad .1$

$-.6$

$-2.1$

$-3.7$

$-19.5$

$-3.2$

$-16.4$

In


with import licensing and rent seeking, the major impacts of reducing tariffs reflect income effects rather than price effects.

In Table 9, results for a series of changes in import licensing are reported. Column 1 increases the value of quotas by $10 \%$, liberalizing developing country trade regimes. As a result, the terms of trade of regions exporting to LDCs and NICs improve. Simultaneously, the reduction in the value of rents produces an improvement in the terms of trade of LDCs and NICs measured to include incremental rent seeking costs. Conventionally measured, their terms of trade deteriorates. Column 2 reports results for a reduction in quota values by $10 \%$; i.e., a tightening of import licensing. This results in a terms of trade deterioration for the North, a conventionally measured terms of trade improvement for the South, but including incremental rent seeking costs a terms of trade worsening. In column 3 licenses are increased by $25 \%$ producing a stronger version of the same features suggested by column 1 .

\section{CONCLUSIONS}

In this paper results are reported for a series of counterfactual experiments with an eight-region numerical general equilibrium model of world trade, production, and welfare. In these analyses trade restrictions in the developing world are modelled as quantity constrained import licensing which generate competitive rent-seeking behavior. Model experiments concentrate on the implications of differential factor endowment growth for the North-South terms of trade, and the effects of alternative trade policy changes in developing countries.

Because existing rent seeking literature has not emphasized the deviation from the traditional trade model which follows from incorporating two rather than one terms of trade between regions when import licensing and rent seeking occur, the results reported here have major implications for the current debate on the North-South terms of trade. Since there is no single measure 
Table 9

Effects of Changes in Import Licenses in the Model

(1)

Quotas in NICs and LDCs increased by 10 percent
(2)

Quotas in NICs and IDCs decreased by 10 percent
(3)

Quotas in NICs and IDCs increased by 25 percent

A. ANNUAL WELFARE IMPACTS

(EVs in \$bill 1977)

EEC

5.9

$-5.7$

15.1

US

2.3

$-2.0$

6.1

Japan

2.8

$-2.7$

7.0

Canada

.5

$-.4$

1.3

Other Developed

3.3

$-3.0$

8.7

OPEC

4.7

$-4.4$

12.1

NICs

17.4

$-16.4$

45.8

LDCs

28.2

$-27.2$

73.0

B. TERMS OF TRADE IMPACTS

(\% change, tve denotes improvement)

EEC
US
Japan
Canada
Other Developed
OPEC
IICs (As Conventiona.1y Jcasured ..
$\quad$ Excluics Incremental Rent
insi-inn)
iICs (Including Incremental
Rent Seeking)
LDCs (As Conventionally Measured -
$\quad$ Excludes Incremental Rent
Seeking)
LDCs (Including Incremental
Rent Seeking)

$\begin{array}{rrr}2.1 & -2.3 & 4.9 \\ 1.2 & -1.3 & 2.6 \\ 2.6 & -2.9 & 6.0 \\ .9 & -.9 & 2.2 \\ 1.4 & -1.5 & 3.4 \\ 3.6 & -3.6 & 8.9 \\ 7.3 & 7.4 & -17.5 \\ 3.4 & & \\ -12.2 & -7.5 & 23.3 \\ 9.3 & 13.9 & -27.7 \\ & & \end{array}$


of the North-South terms of trade, it is possible that as the severity of import restrictions in the developing world has intensified in the post-war years, the terms of trade including incremental rent-seeking costs may have been deteriorating through time for all regions. Also reducing tariffs but leaving licensing unchanged can increase the value of rents and increase the rent seeking costs associated with trade policies. 


\section{Bibliography}

Alamgir, M. (1968) "The Domestic Prices of Imported Commodities in Pakistan: A Further Study", Pakistan Development Review, Vol. VIII, No. 1, Spring, pp. 35-73.

Armington, P.S. (1969) "A Theory of Demand for Products Distinguished by Place of Production", International Monetary Fund Staff Papers, pp. 159-176.

Balassa, B.A. (1971) The Structure of Protection in Developing Countries. Baltimore: John Hopkins Press for the International Bank for Reconstruction and Development and the Inter-American Development Bank.

Balassa, B. and M.E. Kreinen. (1967) "Trade Liberalization Under the 'Kennedy Round': The Static Effects". Review of Economics and Statistics. Vol. 58, February, pp. 59-68.

Bhagwati, J.N. (1958) "Immiserizing Growth: A Geometrical Note" Review of Economic Studies, Vol. 25, No. 3, June, pp. 201-205.

Bhagwati, J.N. and T.N. Srinivasan. (1980) "Revenue Seeking: A Generalization of the Theory of Tariffs", Journal of Political Economy, Vo1. 88, No. 6 .

Bhuyan, A.R. and W. Mahmud. (1979) "Domestic Prices of Imports: An Analysis of Trading Margins Under Exchange Control", mimeo, Planning Commission Bangladesh.

Deardorff, A.V. and R.M. Stern. (1981) "A Disaggregated Model of World Production and Trade: An Estimate of the Impact of the Tokyo Round", Journal of Policy Modelling, Vo1. 13, No. 2, pp. 127-152.

Houthakker, H.S. and S.P. Magee. (1969) "Income and Price Elasticities in World Trade", Review of Economics and Statistics, Vol. LI, No. 2, May, pp. $111-125$.

Kehoe, T.J. and J. Whalley (1982) "Uniqueness of Equilibrium in Large-Scale Numerical General Equilibrium Models" (mimeo), University of Western Ontario.

Kemp, M.C. (1962) "Errors of Measurement and Bias in Estimates of Import Demand Parameter s", Economic Record, Vol. 38, No. 83, September, pp. 369-372.

Khan, M.S. (1974) "Import and Export Demand in Developing Countries", IMF Staff Papers 21, November, pp. 678-693. 
Krueger, A. O. (1974) "The Political Economy of the Rent-Seeking Society," American Economic Review, June, Vol. 64, pp. 291-303.

Mansur, A. H. and J. Whalley (1984) "Numerical Specification of Applied General Equilibrium Models: Estimation, Calibration, and Data" in H. Scarf and J. Shoven (eds.) Applied General Equilibrium Analysis New York: Cambridge University Press.

Michaely, M. (1980) "The Terms of Trade Between Rich and Poor Nations," Paper No. 162, Institute for International Economic Studies, University of Stockholm.

Mohammad, S. and J. Whalley (1984) "Rent Seeking in India: Its Costs and Policy Significance," Kyklos, September (to appear).

Nguyen, D.T. and A.R. Bhuyan (1977) "Elasticities of Export and Import Demand In Some South Asian Countries: Some Estimates", Bangladesh Development Studies, Vol. V, No.s 2, April, pp. 133-152.

Orcutt, G.H. (1950) "Measurement of Price Elasticities in International Trade", Review of Economics and Statistics, Vol. 32, May, pp. 117-132.

Prebisch, R. (1950) "The Economic Development of Latin American and its Principal Problems" Economic Bulletin for Latin America, No. 7, pp. 1-22. (First published as an independent booklet by UN ECLA.

Scarf, H. (1973) (With the collaboration of Terje Hansen). The Computation of Economic Equilibria. New Haven: Yale University Press.

Shiells, C.R., R.M. Stern and A.V. Deardorff (1983) "Estimates of the Elasticities of Substitution Between Imports and Home Goods for The United States", University of Michigan Working Paper No. 183, Institute of Public Policy Studies, January.

Shoven, J. B. and J. Whalley (1972) "A General Equilibrium Calculation of the Effects of Differential Taxation of Income from Capital in the U.S.," Journa1 of Public Economics, Vo1. 1, No. 3/4, November, pp. 281-321.

(1973) "General Equilibrium with Taxes:

A Computational Procedure and an Existence Proof", Review of Economic Studies, October, Vol. 60, pp. 475-490.

(1974) "On the Computation of Competitive Equilibrium on International Markets with Tariffs", Journal of International Economics. Vol. 4, No. 4, November, pp. 341-354. 
Shoven, J.B. and J. Whalley. (1984) "Applied General Equilibrium Models of Taxation and International Trade", Journal of Economic Literature September (to appear).

Singer, H.W. (1950) "The Distribution of Gains Between Investing and Borrowing Countries", American Economic Review, May pp. 473-85.

Sproas, J. (1980) "The Statistical Debate on the Net Barter Terms of Trade between Primary Commodities and Manufactures" Economic Journal, Vol. 90, March, pp. 107-128.

Stern, R.M. et al. Price Elasticities in International Trade: An Annotated Bibliography. London: Macmilian for the Trade Policy Centre.

Stone, J.A. "Price Elasticities of Demand for Imports and Exports: Industry Estimates for the U.S., the EEC, and Japan", Review of Economics and Statistics, Vol. LXI, May, pp. 306-312.

Taplin, G.B. (1979) "A Model of World Trade", ed. R.J. Ball, The Inernational Linkage of National Economic Models, NorthHolland.

Weisskoff, R. (1979) "Trade, Protection and Import Price Elasticities for Brazil", Review of Economics and Statistics, Vol. LXI, No. 1, February, pp. 58-66.

Whalley, J. Trade Liberalization Among Major World Trading Areas. MIT Press (forthcoming).

Whalley, J. (1984) "The North-South Debate and Terms of Trade: An Applied General Equilibrium Approach" The Review of Economics and Statistics, forthcoming.

Whalley, J. (1982) "An Evaluation of the Tokyo Round Trade Agreement Using General Equilibrium Computational Methods" Journal of Policy Modelling, Vol. 4, No. 3, November, pp. 341-363.

Yeats, A.J. (1979) Trade Barriers Facing Developing Countries: Commerical Policy Measures and Shipping. London: Macmillan. 
81010

$8102 \mathrm{C}$

$8103 C$

$8104 C$

$8105 \mathrm{C}$

$8106 C$

$8107 \mathrm{C}$

8108C D gJ

8109 C D S

81100

\&111C

82010

$8202 C$

$8.203 \mathrm{C}$

$8204 \mathrm{C}$

82050

$\therefore 2000$

$8207 \mathrm{C}$

$\therefore 208 \mathrm{C}$

$8209 \mathrm{C}$ DSU
Markusen, James R. Factor Movements and Commodity Trade as Compliments: A Gurvey of some Cases.

Conlon, R.M. Comparison of Australian and Canadian Manufacturing Industries: Some Empirical Evidence.

Conlon, R.M. The Incidence of Transport Cost and Tariff Protection: Some Australian Evidence.

Laidler, David. On the Case for Gradualism.

Wirick, Ronald G. Rational Expcctations and Rational Stabilization Policy in an Open Economy

Mansur, Ahsan and John Whalley Numerical quecification of Applied General Equilibrium Models: Estimation, Calibration, and Data.

Burgess, David F., Energy Prices, Capital Formation, and Potential GNP

Jimenez, E. and Douglas $\mathrm{H}$ Keare. Housing Consumption and Income in the Low Income Urban Setting: Estimates from Panel Data in El Salvador

Whalley, John Labour Migration and the North-South Debate

Manning, Richard and John McMillan Government Expenditure and Comparative Advantage

Freid, Joel and Peter bowitt Why Inflation Reduces Real Interest Rates

1982

Manning, Richard and James R. Markusen Dynamic Non-Substitution and Long Run Production Possibilities

Feenstra, Robert and Ken Judd Tariffs, Technology Transfer, and Welfare

Ronald W. Jones, and Douglas D. Purvis: International Differences in Response to Common External Ghocks: The Role of Purchasing Power Parity

James A Brander and Barbara J. Spencer: Industrial Strategy with Committed Firms

Whalley, John, The North-South Debate and the Terms of Trade: An Applied General Equilibrium Approach

Roger Betancourt, Christopher Clague, Arvind Panagariya CAPI TAL UTIIIIZATI ON IN GENERAL EQUILIBRIUM

Mansur, Ahsan $\mathrm{H}$, On the Estimation of Import and Export Demand Elasticities and Elasticity Pessimisin.

Whalley, J. and Randy Wigle PRICE AND QUANTITY RIGIDITIES IN ADJUSTMENT TO TRADE POLICY CHANGES: ALTERNATIVE FORMULATIONS AND INITIAL CALCULATIONS

Jimenez, E. SQUATTING AND COMMUNITY ORGANIZATION IN DEVELOPING COUNTRIES: A CONCEPTUAL FRAMLWORK 
8210C Grossman, G.M. INTERNATIONAL COMPETITION AND THE UNIONIZED SECTOR

8211C Laidler,D. FRIEDMAN AND SCHWARTZ ON MONETARY TRENDS - A REVIEW ARTICLE

8212C Imam, M.H. and Whalley, J. INCIDENCE $\Lambda$ NALYSIS OF $\Lambda$ SECTOR SPECIFIC MINIMUM WAGE IN A TWO SECTOR HARRIS-TODARO MODEL.

8213C Markusen, J.R. and Melvin, J.R. THE GAINS FROM TRADE THEOREM WITH INCREASING RETURNS TO SCALE.

8214C INDUSTRIAL ORGANIZATION AND THE GENERAL EQUILIBRIUM COSTS OF PROTECTION IN SMALL OPEN ECONOMIES.

Y215C Laidler, D. DID MACROECONOMICS NEEI THE RATIONAL EXPECTATIONS REVOLUTION?

$8216 \mathrm{C}$ Whalley, J. and Wigle, R. ARE DEVELOPED COUNTRY MULTILATERAL TARIFF REDUCTIONS NECESSARILY BENEFICIAL FOR THE U.S.?

$8217 \mathrm{C}$ Bade, R. and Parkin, M. Is STERLING M3 THE RIGHT AGGREGATE?

82180 Kosch, B. FIXED PRICE FOUUILIBRIA IN OPEN FCONOMIES.

1983 B301C Kimbell, L.J. and Harrison, G.W. ON THE SOLUTION OF GENERAL EQUILIBRIUM
MODELS.

S302: Melvin, J.R. A GENERAL EQUILIBRIUM ANALYSIS OF .CANADIAN OIL POLICY.

33036: Markusen, J.R. and Svensson, L.F.O. TRADE IN GOODS AND FACTORS WITH INTERNATIONAL DIFFERENCES IN TECHNOLOCY.

830\%: Mohammad, S. Whalley, J. RENT SEEKINC IN INDIA: ITS COSTS AND POLICY SIGNIFICANCE.

8305C DSU Jimenez, E. TENURE SECURITY AND URBAN SỌUATTING.

$8306 \mathrm{C}$ Parkin, M. WHAT CAN MACROECONOMIC THEORY TELL US ABOUT THE WAY DEFICITS SHOULD BE MEASURED.

3307C Parkin, M. THE INILATION DEBATE: AN ATTEMPT TO CLEAR THE AIR.

8308c Woton, I. LABOUR MIGRATION IN $\Lambda$ MODEL OF NORTH-SOUTH TRADE.

5309C Deardorff, A.V. THE DIRECTIONS OF DEVELOPING COUNTRIES TRADE: EXAMPLES FRONI PURE THEORY.

: $310 \mathrm{C}$ Manning, $\mathrm{R}$. ADVANTAGEOUS REALLOCATIONS AND MULTIPLE EQUILIBRIA: RESULTS FOR THE THREE-AGENT TRANSFER PROBIFM. 
$8311 C$ DSU Mohammad, S. and Whalley, J. CONTROLS AND THE INTERSECTORAL TERMS OF TRADE IN INDIA.

8312C Brecher, Richard A. and Choudhr1, Ehsan U. NEW PRODUCTS AND THE FACTOR CONTENT OF INTERNATIONAL TRADE.

$8313 \mathrm{C}$ Jones, R.W., Neary, J.P. and Ruane, P.P. TWO-WAY CAPITAL FLOWS: CROSSHAULING IN A MODEL OF FOREIGN INVESTMENT.

$8314 C$ DSU Follain, J.R. Jr. and Jimenez, E. THE DEMAND FOR HOUSING CHARACTERISTICS IN DEVELOPING COUNTRIES.

8315C Shoven, J.B. and Whalley, J. APPLIED GENERAL EQUILIBRIUM MODELS OF TAXATION AND INTERNATIONAL TRADE.

8316C Boothe, Paul and Longworth David. SOME IRREGULAR REGULARITIES IN THE CANADIAN/U.S. EXCHANGE MARKET.

8317C Hamilton, Bob and Whalley, John. BORDER TAX ADJUSTMENTS AND U.S. TRADE.

8318C Neary, J. Peter, and Schwelnberger, Albert G. FACTOR CONTENT FUNCTIONS AND THE THEORY OF INTERNATIONAL TRADE.

8319C Veall, Michael R. THE EXPENDITURE TAX AND PROGRESSIVITY.

8320C Melvin, James R. DOMESTIC EXCHANGE, TRANSPORTATION COSTS AND INTERNATIONAL TRADE.

8321C Hamllton, Bob and Whalley, John. GEOGRAPHICALLY DISCRIMINATORY TRADE ARRANGEMENTS.

8322C Bale, Harvey Jr. INVESTMENT FRICTIONS AND OPPORTUNITIES IN BILATERAL U.S.-CANADIAN TRADE RELATIONS.

8323C Wonnacott, R.J. CANADA-U.S. ECONOMIC RELATIONS-A CANADIAN VIEW.

8324C Stern, Robert M. U.S.-CANADIAN TRADE AND INVESTMENT FRICTIONS: THE U.S.: VIEW.

8325C Harrison, Glenn, H. and Kimbell, Larry, J. HOW ROBUST IS NUMERICAL GENERAL EQUILIBRIUM ANALYSIS?

8326C Wonnacott, R.J. THE TASK FORCE PROPOSAL ON AUTO CONTENT: WOULD THIS SIMPLY EXTEND THE AUTO PACT, OR PUT IT AT SERIOUS RISK?

8327C Bradford, James C. CANADIAN DEFENCE TRADE WITH THE U.S. Conklin, David. SUBSIDY PACTS.

Rugman, Alan M. THE BEHAVIOUR OF U.S. SUBSIDARIES IN CANADA:

IMPLICATIONS FOR TRADE AND INVESTMENTS. 


\begin{abstract}
$8328 \mathrm{C}$ Boyer, Kenneth D. U.S.-CANADIAN TRANSPORTATION ISSUES.
8329C Bird, Richard M. and Brean, Donald J.S. CANADA-U.S. TAX RELATIONS: ISSUES AND PERSPECTIVES.

8330C Moroz, Andrew R. CANADA-UNITED STATES AUTOMOTIVE TRADE AND TRADE POLICY ISSUES.

8331C Grey, Rodney de C. and Curt1s, John. INSTITUTIONAL ARRANGEMENTS FOR. U.S.-CANADIAN NEGOTIATIONS. PART I: CANADA-U.S. TRADE AND ECONOMIC ISSUES: DO WE NEED A NEW INSTITUTION? PART II: INSTITUTIONAL ARRANGEMENTS FOR MANAGING THE CANADA-U.S. ECONOMIC RELATIONSHIP.
\end{abstract}

\title{
1984
}

8401C Harrison, Glenn $\mathrm{W}$. and Manning, Richard. BEST APPROXIMATE AGGREGATION OF INPUT-OUTPUT SYSTEMS.

8402C Parkin, Michael. CORE INFLATION: A REVIEW ESSAY.

8403C Blomqvist, Ảke, and McMahon, Gary. SIMULATING COMMERICAL POLICY IN A SMALL, OPEN DUAL ECONOMY WITH URBAN UNEMPLOYMENT: A GENERAL EQUILIBRIUM APPROACH.

8404C Wonnacott, Ronald. THE THEORY OF TRADE DISCRIMINATION: THE MIRROR IMAGE OF VINERIAN PREFERENCE THEORY?

8405C Whalley, John. IMPACTS OF A 50\% TARIFF REDUCTION IN AN EIGHT-REGION GLOBAL TRADE MODEL.

8406C Harrison, Glenn W. A GENERAL EQUILIBRIUM ANALYSIS OF TARIFi' REDUCTIONS.

8407C Horstmann, Ignatius and Markusen, James R. STRATEGIC INVESTMENTS AND . THE DEVELOPMENT OF MULTINATIONALS.

8408C Gregory, Allan W. and McCurdy, Thomas H. TESTING THE UNBIASEDNESS HYPOTHESIS IN THE FORWARD FOREIGN EXCHANGE MARKET: A SPECIFICATION ANALYSIS.

8409C Jones, Ronald H. and Kierzkowski, Henryk. NEIGHBORHOOD PRODUCTION STRUCTURES WITH APPLICATIONS TO THE THEORY OF INTERNATIONAL TRADE.

$8410 \mathrm{C}$ Weller, Paul and Yano, Makoto. THE ROLE OF FUTURES MARKETS IN INTERNATIONAL TRADE: A GENERAL EỌUILIBRIUM APPROACH.

8411C Brecher, Richard A. and Bhagwati, Jagdish N. VOLUNTARY EXPORT RESTRICTIONS VERSUS IMPORT RESTRICTIONS: A WELFARE-THEORETIC COMPARISON. 
8412C Ethier, Wilfred J. ILLEGAL IMMIGRATION.

8413C Eaton, Jonathon and Gene M. Grossman. OPTIMAL TRADE AND INDUSTRIAL POLICY UNDER OLIGOPOLY.

$8414 \mathrm{C}$ Wooton, Ian. PREFERENTIAL TRADING AGREEMENTS - A 3xn MODEL.

8415C Parkin, Michae1. DISCRIMINATIN, BETWEEN KEYNESIAN AND

CLASSICAL THEORIES OF THE BUSINESS CYCLE JAPAN 1967-1982

8416C Deardorff, Alan V. FIRless FIRwoes: HOW PREFERENCES CAN INTERFERE WITH THE THEOREMS OF INTERNATIONAL TRADE.

8417C Greenwood, Jeremy. NONTRADED GOODS, THE TRADE BALANCE, AND THE BALANCE OF PAYMENTS.

8418C Blomqvist, Ake and Sharif Mohammad. CONTROLS, CORRUPTION, AND COMPETITIVE RENT-SEEKING IN LDCS.

8419C Grossman, Herschel I. POLICY, RATIONAL EXPECTATIONS, AND POSITIVE ECONOMIC ANALYSIS.

8420C Garber, Peter M. and Robert G. King. DEEP STRUCTURAL EXCAVATION? A CRITIOUUE OF EULER EQUATION METHODS.

$8421 \mathrm{C}$ Barro, Robert J. THE BEHAVIOR OF U.S. DEFICITS.

8422C Persson, Torsten and Lars E.0. Svensson. INTERNATIONAL BORROWING AND TIME-CONSISTENT FISCAL POLICY.

8423C Obstfeld Maurice. CAPITAL CONTROLS, THE DUAL EXCHANGE RATE, AND DEVALUATION.

8424C Kuhn, Peter. UNION PRODUCTIVITY EFFECIS AND ECONOMIC EFFICIENCY.

8425C Hamilton, Bob and John Whalley. TAX TREATMENT OF HOUS ING IN A DYNAMIC SEỌUENCED GENERAL EOUUILIBRIUM MODEL.

8426C Hamilton, Bob, Sharif Mohammad, and John Whalley. RENT SEEKING AND THE NORTH-SOUTH TERMS OF TRADE. 